\title{
Teachers' social and emotional competencies in nursing technical education
}

\author{
Competências socioemocionais de professores na educação técnica em enfermagem \\ Competencias socioemocionales de profesores en la educación técnica en enfermería
}

'Universidade Federal de São Paulo. São Paulo, São Paulo, Brazil.

Camila Moraes de Azevedo'
ORCID: 0000-0002-6023-7232

Alexandre Pazetto Balsanelli' ORCID: 0000-0003-3557-1061

Luiza Hiromi Tanaka' ORCID: 0000-0003-4344-1116

How to cite this article: Azevedo CM, Balsanelli AP, Tanaka LH. Teachers' social and emotional competencies in nursing technical education Rev Bras Enferm. 2021;74(6):e20210109. https://doi.org/10.1590/0034-7167-2021-0109

\section{Corresponding author:}

Camila Moraes de Azevedo

E-mail:moraesdeazevedo.camila@gmail.com

EDITOR IN CHIEF: Antonio José de Almeida Filho ASSOCIATE EDITOR: Fátima Helena Espírito Santo

Submission: $03-08-2021$

Approval: 04-11-2021

\section{ABSTRACT}

Objectives: to identify the socio-emotional competencies in teachers who work in a Nursing technical course. Method: qualitative study in the action research modality. Inclusion criteria: being a teacher in a Nursing technical course. Data collection: December 2018 to June 2019, with the realization of five focus group meetings. Data analyzed using the Content Analysis technique, according to Bardin. Results: data classification into two categories: 1) Teacher socio-emotional competencies in a conceptual and experiential perspective; 2) Teacher socioemotional competencies in a conscious perspective of lived experiences. Final Considerations: five socio-emotional competencies were listed for teaching practice: self-control, creativity, empathy, respect, and knowing how to listen. There was a strong awareness of the theme among teachers, impacting their teaching practice.

Descriptors: Nursing Education; Competency-Based Education; Education; Technical Nursing Education; Social Skills.

\section{RESUMO}

Objetivos: identificar as competências socioemocionais com professores que atuam num curso técnico em Enfermagem. Método: estudo qualitativo na modalidade da pesquisaação. Critérios de inclusão: ser professor de um curso técnico em Enfermagem. Coleta de dados: dezembro de 2018 a junho de 2019, com a realização de cinco encontros de grupo focal. Dados analisados utilizando-se a técnica de Análise de Conteúdo, segundo Bardin. Resultados: foram classificados em duas categorias: 1) Competências socioemocionais do professor em uma perspectiva conceitual e vivencial; 2) Competências socioemocionais do professor em uma perspectiva consciente das experiências vividas. Considerações Finais: foram elencadas cinco competências socioemocionais para a prática docente: autocontrole, criatividade, empatia, respeito e saber ouvir. Houve forte conscientização do professorado sobre a temática, com impacto na sua prática docente.

Descritores: Educação em Enfermagem; Educação Baseada em Competências; Educação; Educação Técnica em Enfermagem; Habilidades Sociais.

\section{RESUMEN}

Objetivos: identificar las competencias socioemocionales con profesores que actúan en curso de Graduación en Auxiliar de Enfermería. Método: estudio cualitativo en la modalidad de la investigación-acción. Criterios de inclusión: ser profesor de un curso de Graduación en Auxiliar de Enfermería. Recolecta de datos: diciembre de 2018 a junio de 2019, con la realización de cinco encuentros de grupo focal. Datos analizados utilizándose la técnica de Análisis de Contenido, según Bardin. Resultados: fueron clasificados en dos categorías: 1) Competencias socioemocionales del profesor en una perspectiva conceptual y vivencial; 2) Competencias socioemocionales del profesor en una perspectiva consciente de las experiencias vividas. Consideraciones Finales: fueron enlistadas cinco competencias socioemocionales para la práctica docente: autocontrol, creatividad, empatía, respeto y saber escuchar. Hubo fuerte concientización del profesorado sobre la temática, con impacto en su práctica docente. Descriptores: Educación en Enfermería; Educación Basada en Competencias; Educación; Graduación en Auxiliar de Enfermería; Habilidades Sociales. 


\section{INTRODUCTION}

Nursing is one of the professions that adds the most services within the health sector, composed of $80 \%$ nursing technicians and assistants and $20 \%$ nurses $^{(1)}$. Therefore, all actions or interventions in this field can be crucial to establish effective connections.

In this context, socio-emotional competencies are necessary to develop nursing professionals and the profession itself from their training on positively influencing the macrosocial and microsocial contexts. Therefore, rethinking the nursing professionals' training becomes essential because, in a certain way, any action or intervention causes an impact on this entangled and complex universe of health ${ }^{(2)}$.

In the teaching plans of the discipline Nursing Service Management, in technical nursing courses in the city of São Paulo, state of São Paulo (SP), Brazil, for example, only $7 \%$ of these competencies are related to knowing how to be ${ }^{(2)}$, within which the socio-emotional competencies would fit.

Frequently, the figure of the nursing teacher, especially in technical courses, does not appear when it comes to practical results in the delivery of health services to individuals and the population. However, this nurse educator often makes the show shine brighter despite being behind the scenes ${ }^{(3) !}$

A bibliographic search conducted in the Scientific Electronic Library Online (SciELO), Latin American and Caribbean Literature on Health Sciences (LILACS), National Library of Medicine (PubMed), and Education Resources Information Center of the Institute of Education Science (ERIC, United States), with the descriptors "Competencies" and "Emotional Intelligence," shows: teachers with more social and emotional competencies teach more efficiently; understand their students' emotions better and are better qualified to provide support in emotionally difficult moments; better cope with and manage student behavior in the classroom, and are quite able to develop social and emotional competencies in students. "These aspects promote the creation of a healthy classroom climate that contributes to academic success, which can increase teacher satisfaction with their job and decrease stress, generating a virtuous cycle ${ }^{(3)}$.

We tried to observe the nursing teacher in the technical nursing course given the scarcity of literature alluding to these professionals.

\section{OBJECTIVES}

To identify social and emotional competencies with teachers who work in a Nursing technical course.

\section{METHODS}

\section{Ethical aspects}

The Comitê de Ética e Pesquisa da Universidade Federal de São Paulo (Research Ethics Committee of the Universidade Federal de São Paulo) (CEP-UNIFESP/EPM) approved the research. According to the recommendations of the Ethics Committee of UNIFESP and Resolution 466/12, the Termo de Consentimento
Livre e Esclarecido (TCLE) (Informed Consent Form-ICF) was signed by the participants before data collection.

\section{Type of study}

In this study, group participation was cooperative since the subjects chose to participate voluntarily, cooperated with the project, and were regularly consulted, according to Tripp ${ }^{(4)}$.

It was guided by the Consolidated Criteria for Reporting Qualitative Research (COREQ) and carried out employing action research - a participatory research method in which the researcher is directly involved with the research problem ${ }^{(5)}$. The object of investigation is not people but social situations and their problems; the objective of action research is to solve or clarify the problems of the observed situation ${ }^{(4)}$.

Therefore, research is not limited to action: it presupposes an increase in the knowledge and level of awareness of the people involved in the situation and an expansion of the researcher's knowledge ${ }^{(6)}$.

\section{Place of study}

The study was conducted with teachers from a technical nursing school in a suburban neighborhood of São Paulo, SP, Brazil, in an area of high social vulnerability. The school stands out for providing comprehensive training to its students with a high impact on improving the teaching-learning process.

\section{Criteria of inclusion and exclusion}

Teachers directly involved with the students of that institution were invited to participate in the research. The following were excluded: teachers on vacation or leave during the data collection in the focus group period.

\section{Population}

Five professionals participated in the research, three nurses, one pedagogue, and one psychologist. They were all women, over 45 years old, and more than five years of teaching experience.

\section{Collection of data}

The data collection was carried out through focus group meetings because they provided active participation. To designate the characterization of the statements, we used the initial P followed by the numeral and the letter $E$, to inform the number of the focus group meeting. The objectives of each meeting were as follows:

- $1^{\circ}$ meeting - $12 / 19 / 2018$. Introduce the research objectives and provide material for the study;

- $2^{\circ}$ meeting - 02/04/2019. Assess the impact of socioemotional competencies and verify the competencies developed;

- $3^{\circ}$ meeting -03/25/2019. Develop the competency framework. Conceptualize the five competencies listed and outline an action plan; 
- $4^{\circ}$ meeting - 04/29/2019. Verify training to achieve socioemotional competencies;

- $5^{\circ}$ meeting - 06/26/2019. Report practical experiences about the five competencies listed.

\section{Data analysis and treatment}

For the analysis, the study followed these steps: 1 . transcription of the recordings; 2 . submission of the text to the evaluation of the participants, who could read and complement and/ or change excerpts, if they thought it necessary; 3 . conference by the participants; 4 . validation of the transcription by other researchers; 5 . coding and indexing of the themes addressed to create categories (establishing two categories and five subcategories); 6 . validation of the categories by other researchers; 7 . interpretation and discussion of the thematic categories based on the scientific literature found on the subject.

The reference for the analysis of the results was Bardin ${ }^{(6)}$, who defines content analysis as a set of communication analysis techniques aimed at obtaining, through systematic and objective procedures to describe the content of messages, "indicators that allow the inference of knowledge about the conditions of production/reception of these messages"(6).

As for the content analysis method, the organization occurred in three chronological poles, according to the mentioned author: 1) pre-analysis; 2 ) exploration of the material; 3 ) treatment of the results.

This study used the theoretical framework on social-emotional competencies of the Instituto Ayrton Senna (Ayrton Senna Institute), whose studies were based on much of the North American international scientific literature ${ }^{(7)}$.

The Instituto Ayrton Senna (IAS) carries out multicenter research in several states of the country, mostly with children and adolescents, students from the municipal and state public schools ${ }^{(7)}$. The summarized definition of socio-emotional competencies can be explained as "individual capacities, which are manifested in the ways of thinking, feeling, and behavior or attitudes to relate with oneself and with others, to set goals, make decisions, and face adverse or new situations ${ }^{(7) "}$.

They can be observed in our established pattern of action and reaction to personal and social stimuli. Among other examples are persistence, assertiveness, empathy, self-confidence, and curiosity to learn ${ }^{(8)}$. Examples of hybrid competencies are creativity and critical thinking since they involve socio-emotional and cognitive skills ${ }^{(9)}$.

The Institute believes that for developing this set of socioemotional competencies during the teaching and learning process, it is necessary to work on or influence actions both in the scope of public policies and pedagogical practices, involving various players in the educational process ${ }^{(7)}$.

\section{RESULTS}

Based on the analysis of the statements of the participants, two thematic categories and their respective subcategories were identified and presented in Chart 1:
Chart 1 - Results of the analysis of the statements produced in the focus group meetings

\begin{tabular}{|l|l|}
\hline Categories & Subcategories \\
\hline \multirow{2}{*}{$\begin{array}{l}\text { 1. Teacher socio-emotional } \\
\text { competencies from a } \\
\text { conceptual and experiential } \\
\text { perspective }\end{array}$} & $\begin{array}{l}\text { 1.a Perception and understanding of } \\
\text { the socio-emotional competencies } \\
\text { needed by the teacher }\end{array}$ \\
\cline { 2 - 2 } $\begin{array}{l}\text { 1.b Definition and understanding of the } \\
\text { teacher's essential social and emotional } \\
\text { competencies listed by the participants }\end{array}$ \\
\cline { 2 - 2 } & $\begin{array}{l}\text { 1.c Perception of the importance of the } \\
\text { teacher-student relationship for the } \\
\text { development of social and emotional } \\
\text { competencies }\end{array}$ \\
\hline \multirow{2}{*}{$\begin{array}{l}\text { 2. Teacher's socio- } \\
\text { emotional competencies in } \\
\text { a conscious perspective of } \\
\text { the lived experiences }\end{array}$} & $\begin{array}{l}\text { 2.a Perception development of the } \\
\text { other and for the other }\end{array}$ \\
\cline { 2 - 2 } & $\begin{array}{l}\text { 2.b Self-perception of socio-emotional } \\
\text { competencies }\end{array}$ \\
\hline
\end{tabular}

\section{Category 1 - Teacher socio-emotional competencies from a conceptual and experimental perspective}

The participants shared the importance of social and emotional competencies and their meaning in conceptual and experiential aspects about themselves. They pointed out some of the most important competencies for the teacher and listed five essential ones to develop in the Nursing technical course. The chosen socio-emotional competencies were defined conceptually and deepened because of their experiential aspects with the students. These competencies were: respect, empathy, listening, creativity, and self-control.

Category 1 was divided into three subcategories described below.

\section{Subcategories:}

\section{1.a) Perception and understanding of the socio-emotional competencies needed by the teacher}

The statements emphasize conceptual definitions of socioemotional competencies in which one participant treats them in a broad way, such as the KHA (knowledge, skills, and attitudes), up to reflections on their relationship with virtues. They also consider that these competencies need to be regulated by self-knowledge and relationships with others, although this is difficult to develop. According to the following statements, one participant highlights the need for preparation to develop these competencies during nursing education:

It's all about posture [...] your KHA: your knowledge, your skills, and your attitudes [...]. (P2E1)

Nurses still leave school, college, thinking they can teach [...] and it's not like that [...] because there are all the pedagogical and psychological issues that they don't have in their training [...] so they will have to develop that [...]. (P2E2)

The following statements refer to some socio-emotional competencies showing how the relationship with the students 
influence and translates the teacher's need to be open to listening to the student, relating this competence to respect, empathy, and self-control, which require commitment as a teacher:

To be open to the other to know how to transmit it [...] and have the patience to wait for the other's time. (P4E1)

Know how to listen. Sometimes teachers think they know everything [...]. (P3E2)

Respect, empathy [...] putting yourself in the other's place [...] this is more difficult [...] learning how to listen, commitment, if I am not committed to this cause, things will not work out [...]. (P2E2)

The following statements point out several competencies needed by the teacher of the Nursing technical course, such as respect, empathy, listening, flexibility, kindness, courtesy, firmness, patience, persistence, organization, creativity, understanding, love, humility, communication, affection, commitment, responsibility, self-knowledge, ethics, self-esteem, appreciation, good coexistence, partnership, and self-control.

Flexibility [...] these girls come from a virtual world [...] what you took two hours to prepare [...] they take two minutes [...]. (P4E2)

I thought the competencies are: patience, persistence, organization, creativity, empathy, understanding, love and then more than love [...] humility. (P4E1)

Based on the diversity of the competencies, the participants chose to deepen into five competencies.

\section{1.b) Definition and understanding of the teacher's es- sential social and emotional competencies listed by the participants}

The social and emotional competencies listed by the participants based on the reflective discussions with the group of teachers were respect, empathy, listening, creativity, and self-control.

The competence "respect" shows the need for an ethical, coherent, and honest attitude of the teacher's way of being and the need to respect the student's way of being.

Respect:

\section{[...] I have to respect other people's opinions [...]. (P3E4)}

Accept people's different ways of being, acting, and thinking even if it is against what you believe, even if it is against what I believe. (P3E3)

Empathy competence means not only putting oneself in the other's shoes but, above all, looking through the other's eyes, connecting with the student genuinely, as shown in the following definition.

Empathy:

There is the issue of empathy; put yourself in the place of the other, look through the other's eyes. We always make this speech [...] Nursing needs to put itself in the other's place for that person [...] from which world that person comes from and, many times, to look at the individual's need, to know the other's need [...]. (P2E1)

Listening was one of the most cited competencies since the first focus group meeting. It is not just to communicate in words but to connect with the student's feelings.

Listening:

You need to have sensitivity. To be interested in the other person [...]. (P2E3)

Creativity, one of the teacher's competencies for teaching, not in the didactic pedagogical aspect, but to motivate the student to be creative, having as a foundation their capacity and the teacher's motivation.

Creativity:

The stimulus has to be relentless [...] to develop other possibilities [...]. (P2E3)

Elaborate different ways to make the other understand [...] but I have to realize their capacity of understanding [...] a daily exercise [...] imagine myself in situations and think how l get out of it [...]. (P3E3)

Self-control is a socio-emotional competence quite familiar for the teacher about the students. The process of developing self-control involves self-knowledge.

Self-control:

To have the wisdom to touch on new ways to reach the other objectively within their capacity of understanding [...] sometimes I can't [...] all of a sudden, I explain "a hundred" times the same thing [...] and then I lose patience [...]. (P3E3)

\section{1.c) Perception of the importance of the teacher-student relationship for the development of social and emotional competencies}

The statements below show how teachers can develop social and emotional competencies through the students' demands in different situations of the teaching and learning processes. These moments involve remembering and reflecting on the experiences lived by the teachers of the Nursing technical course and, above all, showing empathy and respect in understanding the student, putting themselves in the other's situation, and feeling in the process of self-knowledge.

Respect:

Inotice it more [in the internship] when you sit next to me [...]. (P2E1)

Sometimes we hold the student back too much [...] "Teacher, can I give an opinion?" "No!" (P3E3)

Empathy:

You need to know where the individual's universe came from, even to see how you must speak [...] you may be talking to a group that doesn't understand you [...] so [...] what is the context of that group? (P2E2) 
Listening:

From the relationship with the other, taking time to listen, reflect and help the other to see new thoughts and actions. (P5E1)

Creativity:

If we want to reach the individual and the matrix has the purpose of forming reflective students [...] how can I have this if the teacher is not reflective [...] if when she speaks, she spews all the content? (P2E2)

Self-control:

The most challenging emotion to tolerate [...] I think is disrespectful [...] when something like this happens [...] I control myself but, I feel like putting my hand on the neck [...]. (P5E4)

\section{Category 2 - Teacher's socio-emotional competencies in a conscious perspective of the lived experiences}

This category has two subcategories: 2 .a presents the results of the experiential practice among teachers, and 2.b, the teacher's experiential application, the development of self-perception of the competencies listed in the teachers' collective.

Subcategories:

\section{2.a) Perception development of the other and for the other}

In the fourth meeting of the focus group, a psychologist who already belonged to the group of teachers participating in this study conducted a dynamic in which each teacher offered feedback to all the others, intending to perceive herself in her speech and listen, seeking to integrate and relate the competencies listed: respect, empathy, listening, creativity, and self-control.

This dynamic brought out the experiences of socio-emotional competencies lived among the Nursing teachers, where one teacher told another about herself.

The following statement exhibits the care taken to practice kind speech, a little ceremonious not to be offensive, partially contributing to the development of their socio-emotional competencies.

This year you are very cheerful, communicative, you have changed your appearance. (P3E4)

The following statement shows the best of the feedback, contributing to developing the listed socio-emotional competencies:

P3 is the firstyear that we are closer [...] you are an accurate professional [...] you can synthesize things [...] you are very optimistic [...] but sometimes everything happens too fast, and you don't think [...]ABC [...] and everything happens at the same time [...] A to Z[...] / feel a pause is missing [...] you are super loving, attentive, affectionate [...]. (P2E4)

\section{2.b) Self-perception of socio-emotional competencies}

For three months, the teachers had the opportunity to experience the five competencies listed by themselves with the students and consciously self-perceive themselves.
The competencies descriptions were complemented based on Category 1.

The following participant's statements show the development of self-knowledge competencies and the relation to self-respect in expressing one's feelings to make students have respect.

Respect:

I thought about self-respect, but in which current situation have I shown respect for others? (P1E3)

As for empathy, the experiential practice with students showed the judgment or criticism perception that teachers can make to the student without understanding the situation. This teacher had the opportunity to think back to when she was a student, and this awareness enabled her to experience the process of empathy.

Empathy:

After these discussions [...] / saw that it is crucial to put yourself in the other's shoes [...] and now, as I am very practical, I think [...] how he is seeing this issue [...] and letting the student develop [...] is the best thing [...] so, then, when I realize that I am speeding up [...] I hit the brakes, go slower [...] when it comes to pharmacology, for example, I noticed that the student didn't understand [...] then I put myself in the student's shoes and, geez [...] can it be that he doesn't see that one number comes after another [...] and I thought: I also had this difficulty [...] / needed to see this through the eyes of others [...]. (P3E5)

The following lines exhibit the self-awareness developed by the perception that when teachers talk too much, students stop talking. The purpose of awareness is to train listening more and talking less. One participant proved that, in this way, students pay more attention in class.

Listening:

As you saw [listening to people], I interrupted a lot [...] I am anxious [...]. (P5E4)

In these last disciplines, Micro/Immunology, I tried to get them to talk more [...] I noticed that they pay more attention when they speak to us than when we keep talking [...]. (P4E5)

The following participant realized that when there was more change in the planned lesson, she would get more frustrated and in a bad mood, understanding that the antidote of hardening would be flexibility, resulting in creativity and willingness to innovate.

Creativity:

[...] when my plans don't work out [...] and I get frustrated, it comes in the form ofbadmoods [...] for example, in class, I had something planned to do, and then I have to change it [...] it seems that it is doesn't' matter to change a plan, but it upsets me [...] / have a hard time waiting [...]. (P4E4)

For the participants, self-control is related to reducing anxiety and practicing patience, resulting in better strategies to contribute to the new generations learning.

Self-control:

[...] for me, the issue is self-control [...] restraint [...] and also listening because of my anxiety [...] to do, do, do [...] so [...] / tried to do the 
following: when I was with the students [...] a teacher also gave me a hint of a change in strategy [...] to get the students to participate more [...] I tried to encourage the students to speak more, and I was more preoccupied with organizing the ideas and directing them [...]. (P4E5)

Another aspect of self-perception about the development of socio-emotional competencies felt by the participants was the welcoming of the teacher herself and the appreciation of sharing among and with the other teachers, according to the following statement:

These questions that you brought up [...] for me were a welcome [...] we are being taken care of [...] we always have to have a moment [...] In P5 you could do that [...] always bring those questions to us [...] what I need [...] what I can develop [...] how you are seeing me [...] we will not say everything we think, but improve, find other ways [...]. (P3E5)

The participants talked about the need to continue the discussions on social and emotional competencies, as well as the development of these competencies to ease teacher and students suffering, appreciating the work done, according to the statements pointed out below:

It is important to have this time [...] it is important to sit down and think like this [...] comment with someone asking for this [...] do a project asking for this [...]. (P4E5)

There was a proposal from the group of Nursing teachers to continue to deepen the knowledge about the social and emotional competencies listed by them.

\section{DISCUSSION}

When approaching the theme of social-emotional competencies with the female teachers of the Nursing technical course, the big question was implementing them in educational practice. The teachers highlighted some conveniences and difficulties in their statements. For example, when they mentioned that the school in question had been concerned about the teaching-learning process since its origin, they considered this a facilitating factor for developing this work. They also mentioned the difficulty of the lack of time reflecting on the theme and the little theoretical knowledge about it. It also seemed difficult to insert this module within the course curriculum since the technical approach is still very much prioritized.

Category 1 evidenced teachers' social-emotional competencies from a conceptual and experiential perspective in almost all statements. Even with an initial lack of knowledge about concepts such as competencies, insecurity, or lack of theoretical ability, they experience this theme in their professional practice without reflecting on them. That is in line with both national and international literature, with mentioning of these socio-emotional competencies, also called soft skills, reflected in the speech and behavior of both students and teachers, even though they are unaware of their applicability ${ }^{(10-12)}$. The fact that the participating teachers had experienced these soft skills and promoted the effectiveness of the teaching-learning process also agrees with the literature ${ }^{(13-14)}$. That was demonstrated, for instance, when one of the teachers participating in the research reported that, after changing her strategy, showing self-control in the Pharmacology class, the student was able to better grasp the abstraction in the medication calculation ${ }^{(13,15-16)}$. Similarly, this fact corroborates the reference approached by Instituto Ayrton Senna, which emphasizes that they can and should be worked in the school environment ${ }^{(7)}$.

In Category 2, teachers participating in the research, through conceptual and experiential reflection on the social and emotional competencies, were able to assume them consciously through the development of the perception of the other and for the other, and their self-perceptions ${ }^{(17)}$. In this study, the objective was to know these competencies in a more schematized way, so that, in a second moment, we could work on their development, first in the teachers, and then applying them to the students, even though both tasks are a two-way street ${ }^{(7)}$.

Also, parallel with the concept of socio-emotional competencies that IAS collects, we observe that it is not just a matter of simply attitude, vocational interest, or personality ${ }^{(18-21)}$. Socio-emotional competence is related to an interrelationship of emotional and social skills that help a person to manage his or her own emotions better, to relate positively with others, to perform various tasks (e.g., studying, working, among others), and to deal with daily demands in a competent manner. These are life skills ${ }^{(7)}$. Socioemotional learning (SSE) involves how such knowledge, attitudes, and skills are acquired to achieve a satisfactory level of socio-emotional competence ${ }^{(21-22)}$.

The competencies proposed by the Instituto Ayrton Senna (IAS) (7,21-23) are presented as vectors to guide the curriculum innovations, mainly when focusing on cognitive and socio-emotional aspects. Responsibility, collaboration, communication, creativity, and self-control become issues to be prioritized in curriculum propositions, at the same time as objects of large-scale assessment $^{(24)}$. The socio-emotional competencies prioritized in this context play a crucial role in achieving school success, but mainly in the future life of children and young adolescents ${ }^{(25)}$. Therefore, recognizing these teachers social and emotional competencies who work in this scenario was a transformative element for the collective awareness of these teachers of the importance of their actions, reactions, and emotional behavior to promote the development and learning of their students ${ }^{(18,27)}$.

It is necessary to develop further studies on these socioemotional competencies to propose their development and systematization in teachers who work in a Nursing technical course.

\section{Study limitations}

There was a limitation regarding the validation of these competencies. In the literature, we could not find any matrix in this context to certify these socioemotional competencies in the teachers of the Nursing technical courses. It would also take more time for the application and validation of these data and an instrument appropriate for this reality.

\section{Contributions to the Fields of Nursing, Health or Public Policy}

The study noticed that these socioemotional competencies in the context of health education in general - and specifically in the area of nursing - are crucial for an effective teaching-learning 
process and are related to the elevation of the quality of nursing care. By contributing to the improvement of relationships, we improve the educational process and, in turn, the health care and the entire Unified Health System (SUS), with the possibility of contributing significantly to public health policies. Therefore, it is an advance for professional improvement beyond the technical issue to promote an effective service delivery that adds value to the work context, specifically in the nursing area.

\section{FINAL CONSIDERATIONS}

This study made it possible to identify and make known the socio-emotional competencies of teachers of a Nursing technical course in São Paulo, SP, Brazil. It listed the most promising socioemotional competencies: respect, empathy, listening, creativity, and self-control. In the research setting, most of these competencies refer to interpersonal relationships. Given the opportunity to experience them in the teaching-learning process, teachers have become more aware of the importance of working with these competencies to train people who are motivated to transform their social and professional reality in a world highly globalized by technology. There were no specific studies on socio-emotional competencies focused on the Nursing technical level, although several of them highlight social skills as relevant to the approach in teaching, both intellectual and practical - for example, concerning the assertiveness of conducting a technique. Initially, we analyzed those competencies in a specific setting, but they can be applied at any other level and to different audiences. This study brings a possibility of future research about these socio-emotional competencies in the analyzed scenario and, also, for the specific audience of teachers. There is a need to validate the socioemotional competencies to scientifically prove their evolution, the unfolding of their development process, and the results in the labor world.

\section{FUNDING}

The author would like to thank the Coordenação de Aperfeiçoamento de Pessoal de Nível Superior (Coordination for the Improvement of Higher Education Personnel) (CAPES) through the Demanda Social Program for financing this study.

\section{REFERENCES}

1. Machado MH, Aguiar WF, Lacerda WF, Oliveira E, Lemos W, Wermelinger M, et al. Características gerais da enfermagem: o perfil sociodemográfico. Enferm Foco 2016;6(1/4):11-17. https://doi.org/10.21675/2357-707X.2016.v7.nESP.686

2. Kobayashi RM, Leite MMJ. Formação de competências administrativas do técnico de enfermagem. Rev Latino-Am Enfermagem. 2004;12(2):221-7. https://doi.org/10.1590/S0104-11692004000200011

3. Marques AM, Tanaka LH, Foz AQB. Avaliação de programas de intervenção para a aprendizagem socioemocional do professor: uma revisão integrativa. RPE [Internet]. 2019 [cited 2021 Mar 05];32(1):35-51. Available from: https://revistas.rcaap.pt/rpe/article/view/15133 https://doi. org/10.21814/rpe.15133

4. Tripp D. Action research: a methodological introduction. Educ Pesqui. 2005;31(3):443-66. https://doi.org/10.1590/\$1517-97022005000300009

5. Thiollent M. Metodologia da pesquisa-ação. São Paulo: Ed Cortez;2011. 194p.

6. Bardin L. Análise de conteúdo. Lisboa: Edições 70;1977. 141p

7. Senna IA. Competências e habilidades socioemocionais[Internet]. 2019[cited 2021 Mar 05]Available from: https://institutoayrtonsenna.org. br/pt-br/guia-educacao-integral-na-alfabetizacao/guia-educacao-integral-na-alfabetizacao-socioemocionais.html

8. Pancorbo G, Laros JA. Validity evidence of the Social and Emotional Nationwide Assessment Inventory. Paidéia. 2017;27(68):339-47. https:// doi.org/10.1590/1982-43272768201712

9. Primi R. Mapping self-report questionnaires for socio-emotional characteristics: what do they measure? Estud Psicol. 2019;36:e180138. https://doi.org/10.1590/1982-0275201936e180138

10. Damasio BF. Mensurando habilidades socioemocionais de crianças e adolescentes: desenvolvimento e validação de uma bateria (nota técnica). Trends Psychol. 2017;25(4):2043-50. https://doi.org/10.9788/tp2017.4-24pt

11. Anunciacion $\mathrm{L}$, Chen $\mathrm{CY}$, Pereira DA. Factor structure of a social-emotional screening instrument for preschool children. Psicol-USF. 2019;24(3):449-61. https://doi.org/10.1590/1413-82712019240304

12. Santos MV, Silva TF da, Spadari GF, Nakano TC. Competências socioemocionais: análise da produção científica nacional e internacional. Rev Interinst Psicol. 2018;11(1):4-10. https://doi.org/10.36298/gerais2019110102

13. Carvalho RS, Silva RD. Currículos socioemocionais, habilidades do século XXI e o investimento econômico na educação: as novas políticas curriculares em exame. Educ Rev. 2017;12(63):173-90. https://doi.org/10.1590/0104-4060.44451

14. Coelho VA, Marchante M, Sousa V, Romão, AM. Programas de intervenção para o desenvolvimento de competências socioemocionais em idade escolar: uma revisão crítica dos enquadramentos SEL e SEAL. An Psicol. 2016;34(1):61-72. https://doi.org/10.14417/ap.966

15. Smolka AB, Laplane AF, Magiolino LS, Dainez D. O problema da avaliação das habilidades socioemocionais como política pública: explicitando controvérsias e argumentos. Educ Soc. 2015;36(130):219-42. https://doi.org/10.1590/ES0101-73302015150030

16. Moreira PA, Pinheiro A, Gomes P. Development and evaluation of psychometric properties of inventory of teachers' perceptions on socioemotional needs. Psicol Reflex Crit. 2013;26(1):67 76. https://doi.org/10.1590/\$0102-79722013000100008 
17. Andrews J, Higson H. Graduate Employability, 'Soft Skills' Versus 'Hard' Business Knowledge: A European Study. J Higher Educ Europe. 2010;32:411-22. https://doi.org/10.1080/03797720802522627

18. Keng L. The perceived importance of soft (service) skills in nursing care: a research study. Nurse EducToday. 2020;85:104302. https://doi. org/10.1016/j.nedt.2019.104302

19. Laari L, Dube BM. Nursing students' perceptions of soft skills training in Ghana. Curationis. 2017;40(1):1-5. https://doi.org/10.4102/ curationis.v40i1.1677

20. Pearson E, McLafferty I. The use of simulation as a learning approach to non-technical skills awareness in final year student nurses. Nurse Educ Pract. 2011;11(6):399-405. https://doi.org/10.1016/j.nepr.2011.03.023

21. Silva DI, Mello DF, Mazza VA, Toriyama ATM, Veríssimo MLÓR. Dysfunctions in the socio emotional development of infants and its related factors: an integrative review. Texto Contexto Enferm. 2019;28: e20170370. https://doi.org/10.1590/1980-265x-tce-2017-0370

22. Cannaerts N, Gastmans C, Dierckx de Casterlé B. “Contribution of Ethics Education to the Ethical Competence of Nursing Students: Educators and Students Perceptions. Nurs Ethics. 2014;21(8):861-78. https://doi.org/10.1177/0969733014523166

23. Morrell BLM, Eukel HN, Santurri LE. Soft skills and implications for future professional practice: Qualitative findings of a nursing education escape room. Nurse Educ Today. 2020;93:32-45. https://doi.org/10.1016/j.nedt.2020.104462

24. Kobayashi RM, Leite MMJ. Desenvolvendo competências profissionais dos enfermeiros em serviço. Rev Bras Enferm. 2010;63(2):243-49. https://doi.org/10.1590/S0034-71672010000200012

25. Durlak JA, Weissberg RP, Dymnicki AB, Taylor RD, Schellinger KB. The impact of enhancing students social and emotional learning: a metaanalysis of school-based universal interventions. Child Develop. 2011;82:405-32. https://doi.org/10.1111/j.1467-8624.2010.01564.x

26. Thungjaroenkul P, Cummings GG, Tate K. Testing the social cognitive career theory in Thai nurses' interest to become nurse educators: $\mathrm{A}$ structural equation modeling analysis. Nurse Educ Today. 2016;44:151-6. https://doi.org/10.1016/j.nedt.2016.05.027 